\title{
KEGIATAN PEMANTAUAN KASUS COVID 19
}

\author{
Indra Karana Napitupulu
}

Sekolah Tinggi Ilmu Kesehatan Dharma Husada Bandung

Email Korespondensi: indrakarana@stikesdhb.ac.id

\begin{abstract}
ABSTRAK
COVID-19 adalah penyakit yang disebabkan Novel Coronavirus 2019. Gejalanya bergejala mirip dengan flu biasa, namun COVID-19 sampai saat ini memiliki fatalitas lebih tinggi dan virus ini juga menyebar dengan sangat cepat karena bisa pindah dari orang ke orang bahkan sebelum orang tersebut menunjukkan gejala. Cara isolasi mandiri dirumah yaitu selalu memakai masker dan membuang masker bekas ditempat yang ditentukan, jika sakit (ada gejala demam, flu dan batuk) maka tetap di rumah. Jangan pergi bekerja, sekolah, ke pasar atau ke ruang publik untuk mencegah penularan masyarakat, manfaatkan fasilitas telemedicine atau sosial media kesehatan dan hindari transportasi publik. Beritahu dokter dan perawat tentang keluhan dan gejala, serta riwayat bekerja ke daerah terjangkit atau kontak dengan pasien COVID-19, selama dirumah, bisa bekerja di rumah. Gunakan kamar terpisah dari anggota keluarga lainya, dan jaga jarak 1 meter dari anggota keluarga, tentukan pengecekan suhu harian, amati batuk dan sesak nafas. Hindari pemakaian bersama peralatan makan dan mandi dan tempat tidur, terapkan perilaku hidup sehat dan bersih, serta konsumsi makanan bergizi, mencuci tangan dengan sabun dan air mengalir dan lakukan etika batuk dan bersin, jaga kebersihan dan kesehatan rumah dengan cairan desinfektan. Selalu berada di ruang terbuka dan berjemur di bawah sinar matahari setiap pagi $( \pm 15-$ 30 menit), Hubungi segera fasilitas pelayanan kesehatan jika sakit berlanjut seperti sesak nafas dan demam tinggi, untuk mendapatkan perawatan lebih lanjut. Tujuan pengabdian masyarakat ini adalah untuk melakukan pemantauan kasus covid 19 di Kota Bandung. Kegiatan pengabdian masyarakat ini memberikan pelayanan dengan melakukan pemantauan agar mengetahui keadaan, kondisi dan perkembangan yang dialami oleh warga yang terpapar covid 19 di Kota Bandung. Hasil pengabdian masyarakat diperoleh seluruh warga yang terpapar covid 19 sudah dalam keadaan sehat dan pulih seperti sedia kala.
\end{abstract}

Kata Kunci: Pemantauan kasus covid 19.

\section{ABSTRACT}

COVID-19 is a disease caused by the 2019 Novel Coronavirus. The symptoms are similar to the common cold, but COVID-19 has so far had a higher fatality and this virus also spreads very quickly because it can move from person to person even before the person shows symptoms. . The way to self-isolate at home is to always wear a mask and throw away used masks in the designated place, if you are sick (symptoms of fever, flu and cough) then stay at home. Do not go to work, school, to the market or to public spaces to prevent community transmission, take advantage of telemedicine facilities or health social media and avoid public transportation. Tell doctors and nurses about complaints and 
symptoms, as well as a history of working in infected areas or in contact with COVID-19 patients, while at home, you can work at home. Use a separate room from other family members, and keep a distance of 1 meter from family members, determine daily temperature checks, observe coughs and shortness of breath. Avoid sharing eating and bathing utensils and bedding, apply healthy and clean living habits, and consume nutritious food, wash hands with soap and running water and practice coughing and sneezing etiquette, keep your home clean and healthy with disinfectant liquid. Always be in an open space and bask in the sun every morning ( $\pm 15-30$ minutes), Contact the health care facility immediately if the illness persists such as shortness of breath and high fever, to get further treatment. The purpose of this community service is to monitor COVID-19 cases in the city of Bandung. This community service activity provides services by monitoring to find out the conditions, conditions and developments experienced by residents exposed to COVID-19 in the city of Bandung. The results of community service were obtained that all residents who were exposed to COVID-19 were in good health and recovered as usual.

Keywords: Monitoring cases of covid 19.

\section{PENDAHULUAN}

Di Kota Bandung, tren penyintas COVID-19 sampai data per 5 April 2020 terus mengalami kenaikan. Berdasarkan data yang dirilis Puscovid Kota Bandung, jumlah penyintas COVID-19 mencapai 47 kasus dimana enam orang pasien dinyatakan sembuh dan 17 orang meninggal serta 24 lainnya terus menjalani perawatan intensif (Andriawan, Dhea., 2020).

Jumlah kasus korban yang meninggal akibat terinfeksi virus corona terus meningkat sejak kasus pertama ditemukan penyintas COVID-19 di Kota Bandung pada 19 Maret 2020 lalu, dan berdasarkan data peningkatan korban meninggal terjadi sejak 1 April 2020. Sehari sebelumnya korban meninggal hanya satu orang saja, namun setelah masuk April, angka meninggal dunia terus meningkat. Total ODP di Kota Bandung mencapai 1.790 orang dimana 950 orang telah selesai dilakukan pemantauan dan 840 orang masih dalam pemantauan. Sedangkan, PDP di Kota Bandung mencapai 200 orang dimana 135 orang masih dirawat dan 65 orang sudah sehat dan pulang. Berdasarkan statistik yang didapat, kasus PDP dan Positif COVID-19 di Kota Bandung di dominasi warga dengan rentang usia 50-59 tahun serta di posisi ke dua di dominasi oleh rentan usia 60-69 tahun (Andriawan, Dhea., 2020).

Berdasarkan data dari pusat informasi covid 19 di Kota Bandung, total kasus terkonfirmasi update tanggal 06 september 2021 jam 19.58 adalah sekitar 41,892 dimana konfirmasi aktif sekitar 667, konfirmasi sembuh sekitar 39,817, dan konfirmasi meninggal sekitar 1,408 (Pusat informasi covid 19 Kota Bandung, 2021).

Civitas Akademika STIKes Dharma Husada Bandung dalam upaya membantu Pemerintah Pusat, Pemerintah Daerah/ Kabupaten dan Kota/Kotamadya dalam kegiatan pemantauan kasus Covid-19. Salah satu peran yang saya lakukan sebagai bagian dari civitas akademika STIKes Dharma Husada Bandung adalah menjadi relawan dalam pemantauan kasus Covid-19. Dalam pemantauan saya menanyakan tentang keadaan, kondisi yang dialami oleh warga yang terpapar covid dan membantu hal-hal yang diperlukan oleh warga dan apabila ada yang diperlukan untuk dibelikan sesuatu dibantu untuk memenuhi kebutuhan yang diperlukan. 


\section{MASALAH}

COVID-19 adalah penyakit yang disebabkan Novel Coronavirus 2019. Gejalanya bergejala mirip dengan flu biasa, namun COVID-19 sampai saat ini memiliki fatalitas lebih tinggi dan virus ini juga menyebar dengan sangat cepat karena bisa pindah dari orang ke orang bahkan sebelum orang tersebut menunjukkan gejala (Pusat Informasi dan Koordinasi Covid 19, 2021).

Pandemi covid-19 sedang melanda indonesia dan dunia. Kematian dan jumlah kasus akibat Covid 19 di indonesia semakin bertambah. Kunci utama keberhasilan dalam menurunkan jumlah kasus Covid-19 adalah partisipasi masyarakat. Salah satu peran yang saya lakukan sebagai bagian dari civitas akademika STIKes Dharma Husada Bandung adalah menjadi anggota satuan tugas Covid 19 dengan memberikan informasi kepada para pengendara mobil di Tol Buah Batu, memberikan masker dan vitamin. Diharapkan setalah memberikan informasi kepada para pengendara mobil di Tol Buah Batu. Memberikan masker dan vitamin dapat meningkatkan pengetahuan tentang Covid-19 dan meningkatkan kesadaran masyarakat untuk mematuhi protokol kesehatan.

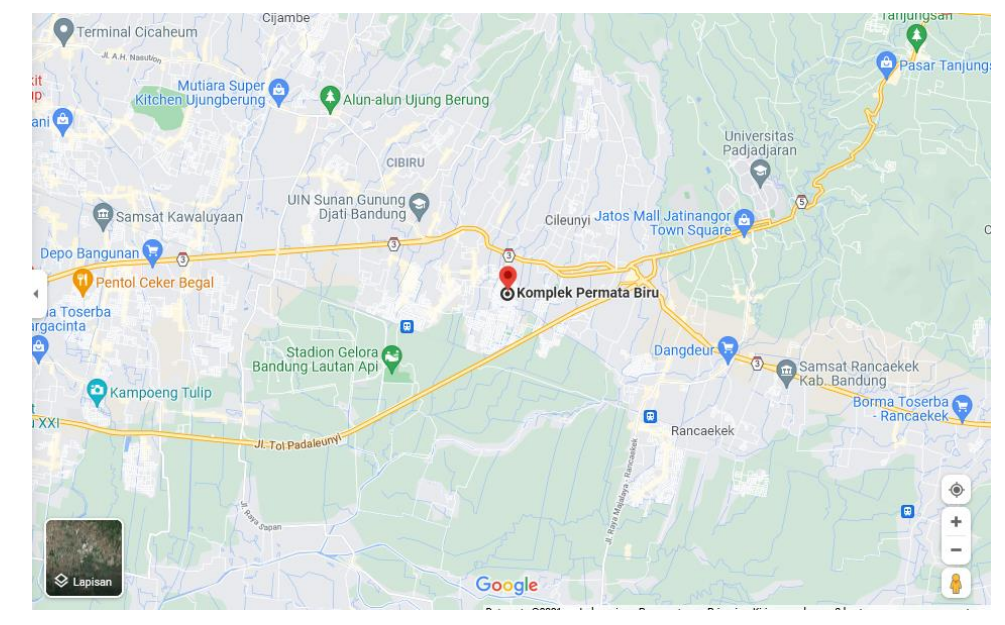

Gambar 2.1 Peta Lokasi Kegiatan Pengabdian kepada Masyarakat

\section{METODE}

\section{a. Tahap persiapan}

Dalam memberikan informasi kepada para warga yang terpapar covid 19 adalah sebagai berikut:

i. Melakukan koordinasi dengan dinas kesehatan dalam kegiatan pemantauan covid 19.

ii. Melakukan identifikasi terhadap para warga yang terpapar covid 19.

b. Tahap pelaksanaan

i. Mengidentifikasi tentang kesehatan warga dan keluarga warga tersebut yang terpapar.

ii. Mengidentifikasi tentang keadaan warga dan keluarga warga tersebut yang terpapar.

iii. Menanyakan apa saja kebutuhan yang diperlukan warga dan keluarga warga tersebut yang terpapar. 
iv. Membantu memenuhi kebutuhan yang diperlukan warga dan keluarga warga tersebut yang terpapar.

v. Mengontrol kembali kesehatan dan warga dan keluarga warga tersebut yang terpapar setiap hari lewat online.

vi. Mengirimkan materi cara isolasi mandiri dirumah.

c. Evaluasi

Warga dan keluarga yang terpapar covid 19, sudah dalam keadaan sehat dan pulih kembali.

\section{HASIL DAN PEMBAHASAN}

Kegiatan ini dikoordinir oleh Dinas Kesehatan Kota Bandung dalam kegiatan pemantauan covid 19, kemudian melakukan identifikasi terhadap para warga yang terpapar covid 19.

Dalam tahap pelaksanaaan saya mengidentifikasi tentang kesehatan warga dan keluarga warga tersebut yang terpapar, kemudian mengidentifikasi tentang keadaan warga dan keluarga warga tersebut yang terpapar, selanjutnya menanyakan apa saja kebutuhan yang diperlukan warga dan keluarga warga tersebut yang terpapar, membantu memenuhi kebutuhan yang diperlukan warga dan keluarga warga tersebut yang terpapar, kemudian mengontrol kembali kesehatan dan warga dan keluarga warga tersebut yang terpapar setiap hari lewat online dan mengirimkan materi cara isolasi mandiri dirumah yaitu 1) selalu memakai masker dan membuang masker bekas ditempat yang ditentukan. 2) jika sakit (ada gejala demam, flu dan batuk) maka tetap di rumah. Jangan pergi bekerja, sekolah, ke pasar atau ke ruang publik untuk mencegah penularan masyarakat. 3) manfaatkan fasilitas telemedicine atau sosial media kesehatan dan hindari transportasi publik. Beritahu dokter dan perawat tentang keluhan dan gejala, serta riwayat bekerja ke daerah terjangkit atau kontak dengan pasien COVID-19. 4) selama dirumah, bisa bekerja di rumah. Gunakan kamar terpisah dari anggota keluarga lainya, dan jaga jarak 1 meter dari anggota keluarga. 5) tentukan pengecekan suhu harian, amati batuk dan sesak nafas. Hindari pemakaian bersama peralatan makan dan mandi dan tempat tidur. 6) Terapkan perilaku hidup sehat dan bersih, serta konsumsi makanan bergizi, mencuci tangan dengan sabun dan air mengalir dan lakukan etika batuk dan bersin. 7) jaga kebersihan dan kesehatan rumah dengan cairan desinfektan. Selalu berada di ruang terbuka dan berjemur di bawah sinar matahari setiap pagi ( $\pm 15-30$ menit). 8) Hubungi segera fasilitas pelayanan kesehatan jika sakit berlanjut seperti sesak nafas dan demam tinggi, untuk mendapatkan perawatan lebih lanjut (p2ptm, kemkes.go.id 2020)

Dan dalam tahap evaluasi warga dan keluarga yang terpapar covid 19, sudah dalam keadaan sehat dan pulih kembali.

Berikut gambar pelaksanaan kegiatan: 


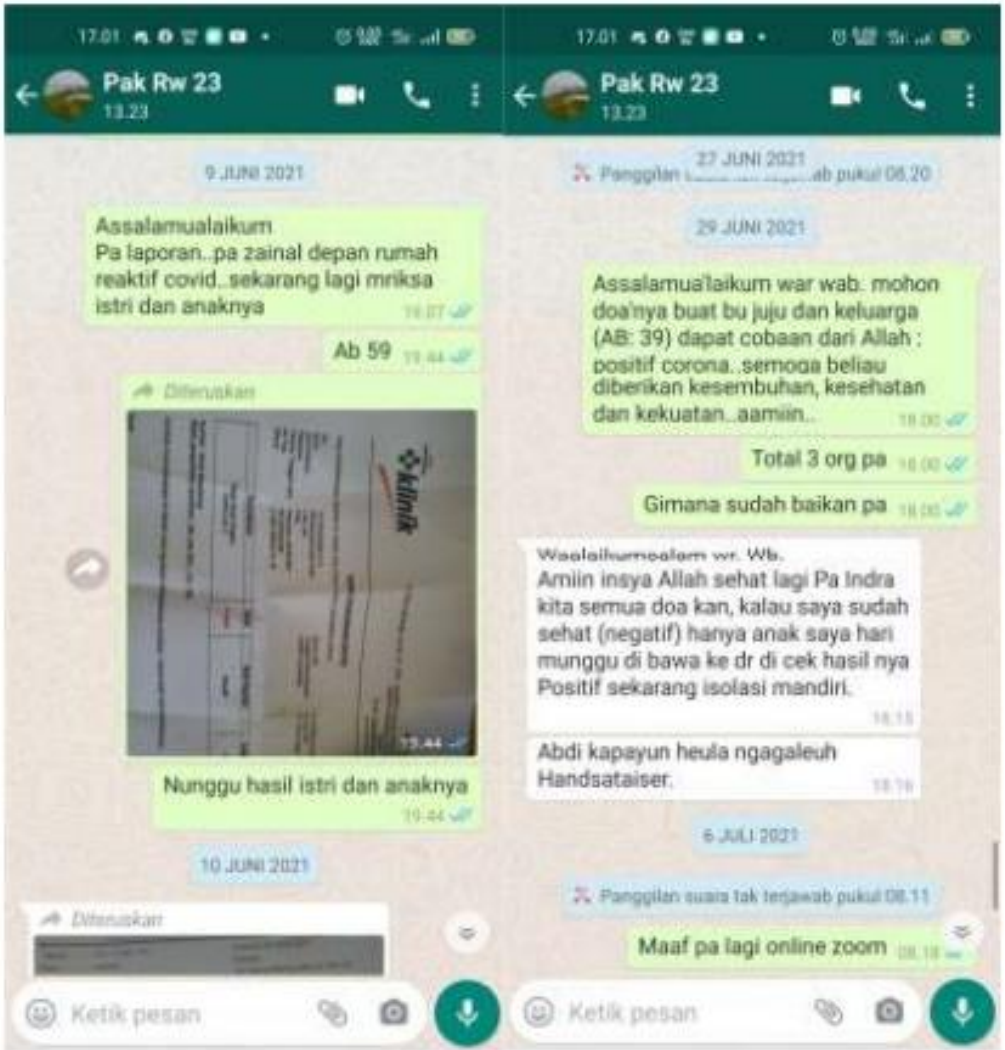

Gambar 2.2 Foto Kegiatan Pemantauan Kasus Covid 19

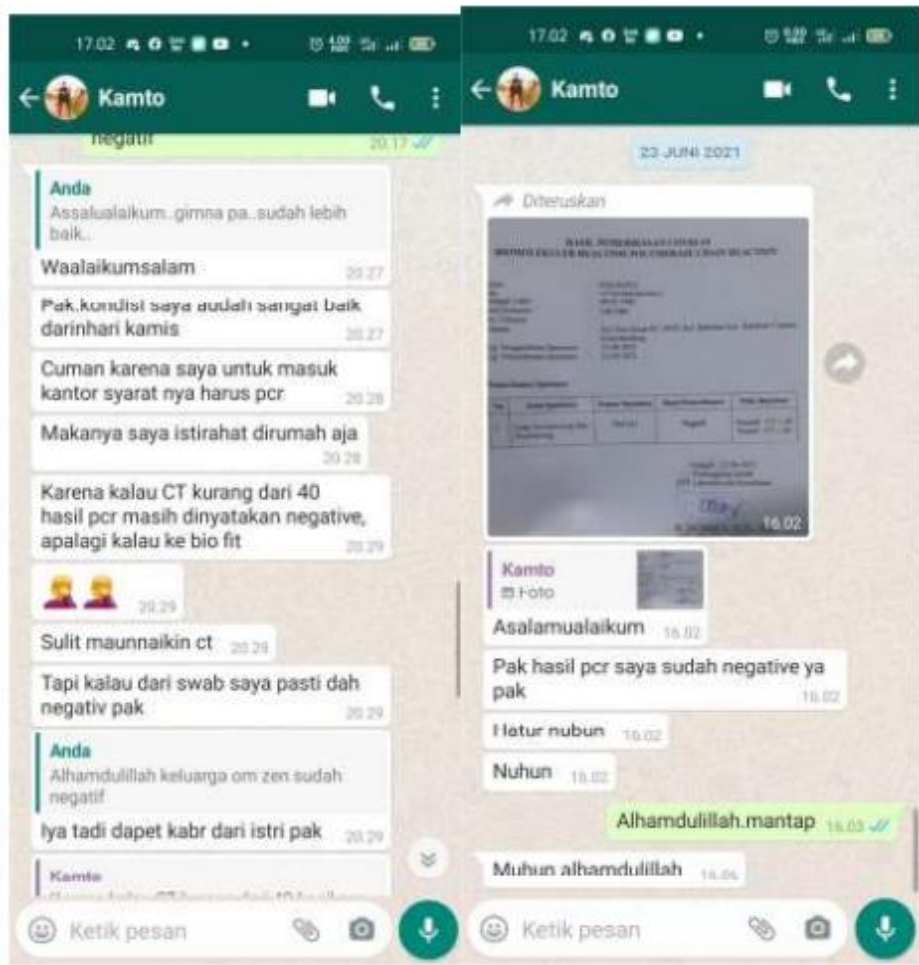

Gambar 2.3 Foto Kegiatan Pemantauan Kasus Covid 19 


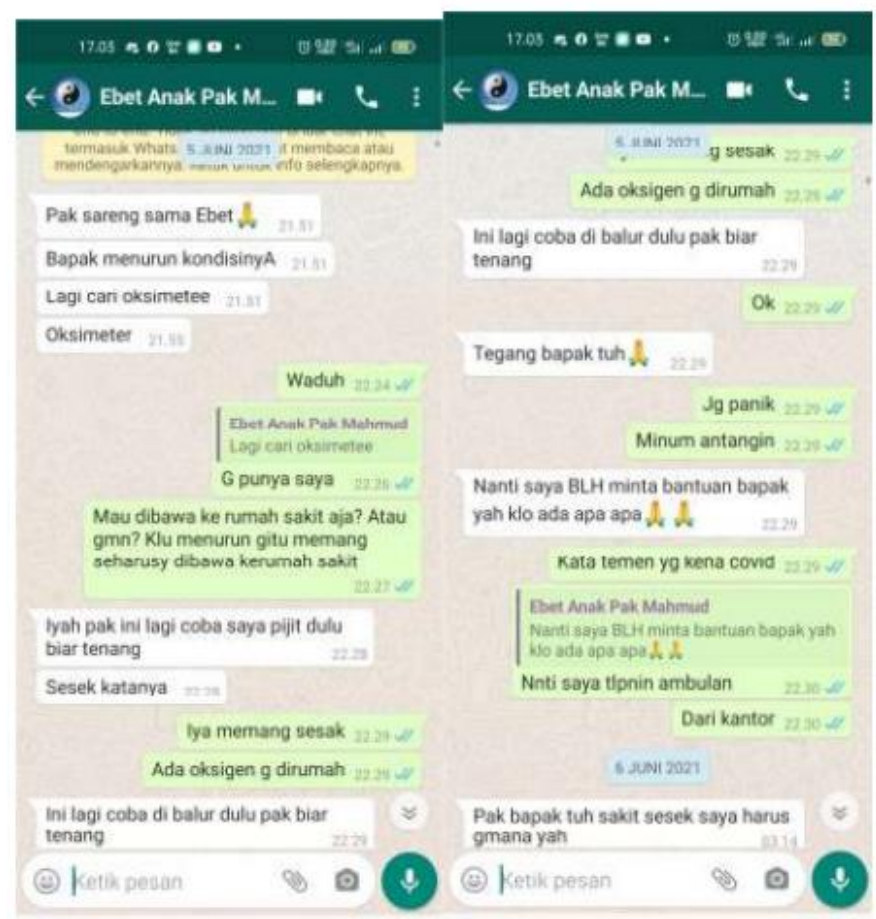

Gambar 2.4 Foto Kegiatan Pemantauan Kasus Covid 19

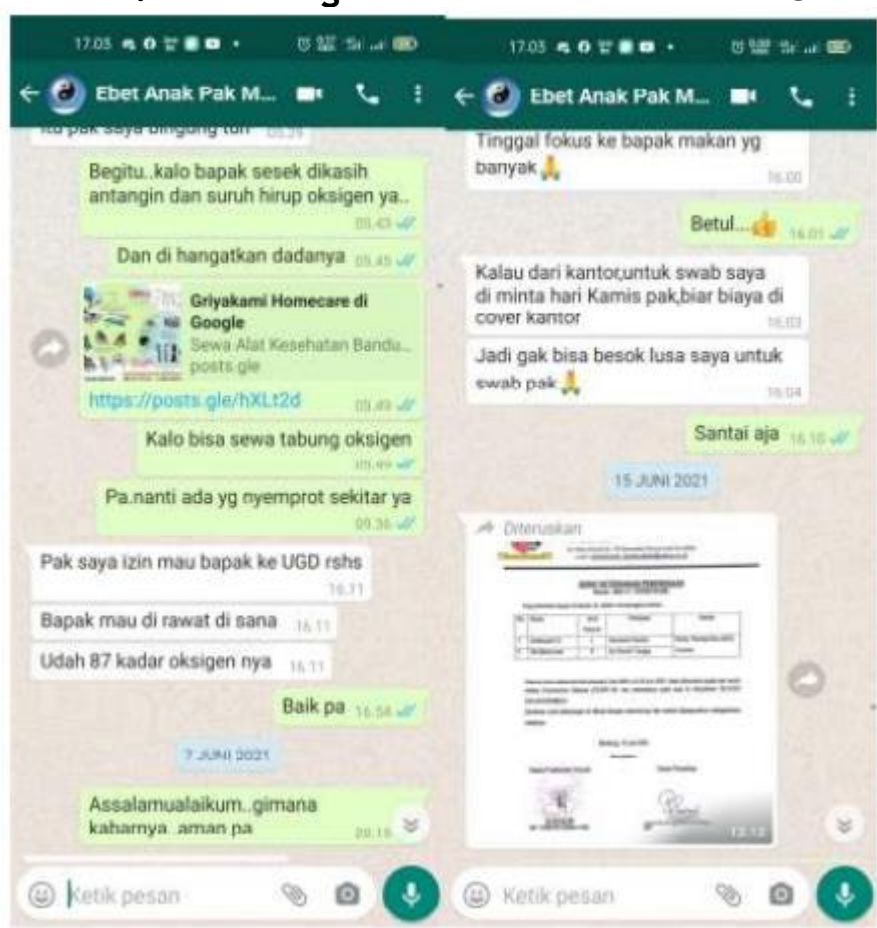

Gambar 2.5 Foto Kegiatan Pemantauan Kasus Covid 19 


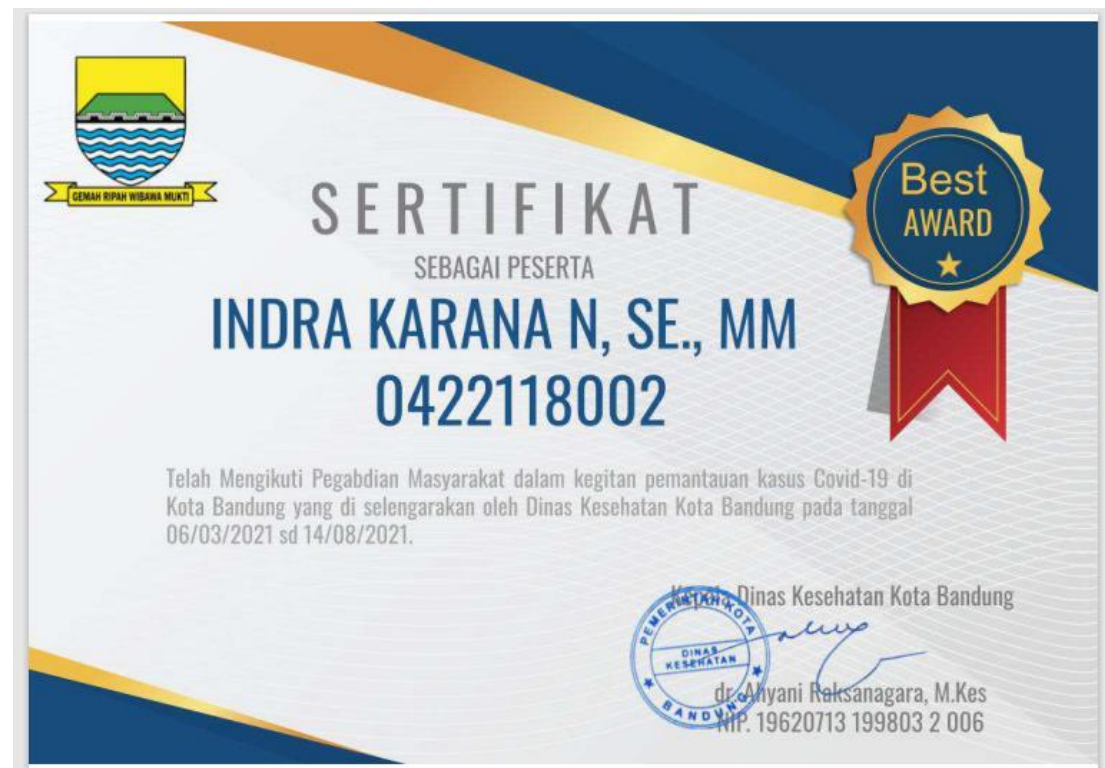

Gambar 2.6 Foto Sertifikat Kegiatan Pemantauan Kasus Covid 19

\section{KESIMPULAN}

Kesimpulan yang diperoleh dari pengabdian kepada masyarakat adalah para warga yang terpapar covid 19 telah sehat dan pulih kembali.

\section{SARAN}

Perlu dilanjutkan kegiatan pemantauan kasus covid-19.

\section{DAFTAR PUSTAKA}

Andriyawan, Dhea (2020) Update COVID-19 di Kota Bandung : Kasus Meninggal Bertambah Jadi 17 Orang, Diunduh dari : https: / /bandung.bisnis.com/read/20200406/549/1222962/update-covid 19-di-kota-bandung-kasus-meninggal-bertambah-jadi-17-orang. Tanggal 07 September 2021

https: / /pikobar.jabarprov.go.id/ Tanggal 07 September 2021

Ketahui risiko dari Covid 19. Pusat Informasi dan Koordinasi Covid-19 Provinsi Jawa Barat. Diunduh dari :

Protokol Isolasi Mandiri Covid 19. Diunduh dari : http://p2ptm.kemkes.go.id/kegiatan-p2ptm/dki-jakarta/protokol-isolasimandiri-covid-19 Tanggal 07 September 2021

Total kasus terkonfirmasi, Diunduh dari : https://covid19.bandung.go.id/. Tanggal 07 September 2021 